\title{
HISTORY
}

\section{RELATIONS BETWEEN UKRAINE AND POLAND AFTER THE FIRST WORLD WAR (1917-1920)}

\author{
Pylypenko L. L., postgraduate student of department of International affairs and social sciences \\ Kyiv, Ukraine, National University of Life and Environmental Sciences of Ukraine
}

DOI: https://doi.org/ 10.31435/rsglobal_ws/31102018/6185

\section{ARTICLE INFO}

Received: 17 August 2018

Accepted: 06 October 2018

Published: 31 October 2018

\section{KEYWORDS}

First World War,

Western Ukraine,

Eastern Galicia,

Poland,

Ukrainian-Polish relations

\begin{abstract}
The article presents the analysis of the main issues related to the formation of the national, cultural, political, confessional selfidentification of the Ukrainian people and the aspirations of its representatives to propose a model of social and political structure that would provide conditions for the development of all Ukrainian citizens in the most appropriate way. As a result, different views of Poles and Ukrainians on this matter at the end of 1918 led to open Ukrainian-Polish political struggle, and later moved, which became a new stage in the cohabitation of the two neighboring peoples.
\end{abstract}

Citation: Pylypenko L. L. (2018) Relations Between Ukraine and Poland After the First World War (1917-1920). World Science. 10(38), Vol.2. doi: 10.31435/rsglobal_ws/31102018/6185

Copyright: (C) 2018 Pylypenko L. L. This is an open-access article distributed under the terms of the Creative Commons Attribution License (CC BY). The use, distribution or reproduction in other forums is permitted, provided the original author(s) or licensor are credited and that the original publication in this journal is cited, in accordance with accepted academic practice. No use, distribution or reproduction is permitted which does not comply with these terms.

Introduction. The events on the territory of modern Ukraine between 1917 and 1920 are the in the focus of scholars, not only due to the turbulent nature of the events of that era, their complexity and dramatic progress, but also due to the extraordinary intellectual richness. During this period, political and public figures had offered and implemented (or attempted to implement) all the models of socio-political structure known at that time:

- by form - from the monarchy to self-government, based on anarchist ideas;

- by content - from the extreme liberal to the extreme totalitarian.

Therefore, it is necessary to analyze the main issues related to the formation of the national, cultural, political, confessional self-identification of the Ukrainian people and the aspirations of its representatives to propose a model of social and political structure that would provide conditions for the development of all Ukrainian citizens in the most appropriate way.

The political situation of the Poles and Ukrainians within the Austro-Hungarian Empire was significantly different [1]. Poles were in conflict with the monarchy because of the desire to gain independence or at least the autonomy of Galicia, which was considered a Polish territory. During this period, the views of the Polish political elite were divided into pro-Austrian and pro-Russian, which in various ways represented the way for the Poles to gain independence. The first of them called for an active struggle for the restoration of statehood on the side of the Central Powers, while the representatives of the second concept put their hopes on Russia, and only then on the western allies.

At the same time, the attitude of Ukrainian politicians towards the aspirations of the Poles was also unclear. First, the Ukrainians hoped for the division of the Kingdom of Galicia and Lodomeria, where the Eastern Galicia, or according to the Ukrainian language tradition - "Galychyna", should become a purely Ukrainian territory [2].

Simultaneous efforts of Ukrainian and Polish national ideologists to draw Eastern Galicia into the process of their own state formation testifies to the transition of Ukrainian-Polish relations to the 
stage of an open political conflict. Both peoples shared the Austrian factor, which for the Poles first of all was a guarantee of the territorial and political unity of Galicia. Polish pro-Austrian orientation in comparison with Ukrainian lasted less, and had many opponents. The activity of the Ukrainian national movement in Galicia aimed at an independent Ukrainian nation, before the war, sometimes created tensions in relations between Russia and Austria-Hungary [3].

As a result of the relationship between the two neighboring nations developed in the direction of conflicts. The main issue was the ethnic boundaries. The intentions of the Ukrainian circles to create their own national state caused alarm to the Galician Poles, as it threatened to cut them off from their people and turn them into a genuine national minority. The response to this threat was different. The attitude of Polish politicians was close to neutral: on the one hand, they understood that the formation of a Ukrainian state in the Dnieper would respond to Galicia and create a threat there for Poland, on the other - they were even more frightened by the danger of the restoration of "great Russia" [4].

The February Revolution of 1917 and the overthrow of tsarism, which created the conditions for the liberation of Ukraine and Poland, had a significant influence on the Polish-Ukrainian relations.

Results. With the fall of autocracy, life put the leaders of the new regime in a fundamentally different kind of problem. To implement the claims for the role of the representative of the revolutionary Ukraine, the national movement had to solve three fundamental problems:

- to renounce its "ultraconational" character;

- to go beyond the narrow circle of the Kyiv intelligentsia, which in turn required the "legalization" of the fundamental principles of the Ukrainian movement;

- to reach a public consensus on the program requirements of this movement.

This, in turn, meant not only the need to resolve the complex relationships between different political circles of Ukraine, but above all the achievement of a consensus on the fundamental issues between the national groups living on the territory of Ukraine.

Already from the first steps of its activities, the Central Committee paid much attention to the issues of Ukrainian-Polish relations. During the period from 1917 to early 1918, Ukrainian-Polish relations did not yet become interstate, as Ukraine was only an autonomy in Russia [4], but the nominal Polish Kingdom also did not constitute a full-fledged state body, because it was in the AustroGermanic dependence. Thus, for Ukraine, the problem of Ukrainian-Polish relations was for some time internal in nature, since after Russians and Jews it was the third largest national minority in Ukraine. Poles supported the aspiration of Ukrainians to self-determination. Polish politicians realized that they would have a greater influence on the political or economic life in the Ukrainian state than in the Russian multinational, but not federal state.

Another important problem facing the UNR was the need to establish relations with the Polish military formations that emerged from the ranks of the former Russian Imperial Army and to determine their status in Ukraine [4]. In fact, they no longer obeyed the Supreme Commander-in-Chief of the Russian Army. For the Ukrainian political movement, this was an important factor in the event of an armed conflict, and also indicated the possibility of Polish-Ukrainian military cooperation.

Fortunately, the process of creating Polish armed units in 1917 did not cause significant UkrainianPolish conflicts. Moreover, when at the turn of 1917-1918 the Bolshevik Russia began its first armed aggression against the UNR, the Ukrainian government tried to secure the support of Polish military formations. And they all chose a position of friendly neutrality to Ukrainians, and some of the Polish units provided assistance to the troops of the Central Council in defending Kyiv from the Bolsheviks.

As a result of the signing of the Brest Peace Treaty in the first half of 1918, the Polish-Ukrainian relations in Galicia became critical. [4] The Brest peace has become a harbinger of the future PolishUkrainian armed conflict, which for some time was held back by Germany and Austria-Hungary, which, after signing the agreement, controlled not only Poland but also Ukraine. At this time, Ukrainian-Polish relations from the internal affairs of Ukraine are beginning to grow into inter-state relations.

Conclusions. Thus, at the final stage of the war, the relationship between the Ukrainian and Polish political forces was characterized by the transition from a temporary position of neutrality of the two peoples to a sharp struggle for ethnic territories [5]. Particularly they worsened when it was a matter of belonging of the Eastern Galicia, which both peoples wanted to see as a part of their state. As a result of such events, at the end of 1918, Ukrainian-Polish relations moved from political struggle to armed, which became a new stage in the cohabitation of the two neighboring peoples. 


\section{REFERENCES}

1. Gruchała J. Rząd austriacki i polskie stronnictwa polityczne w Galicji wobec kwestii ukraińskiej (18901914). Katowice: Uniwersytet Śląski, 1988. c. 146.

2. Borders of Ukraine: history and the problem of formation. 1917-1940 Boyechko V., Ganja O., Zakharchuk B., Kyiv, 1992, Ukrainian Historical Magazine. - No. 1, pp. 62-68. [Kordony Ukrayiny: istoriya ta problema formuvannya. 1917-1940 rr. Boyechko V., Ganzha O., Zaxarchuk B., Kyiv, 1992 p., Ukrayinskyj istorychnyj zhurnal. - \# 1, ss. 62-68.] (In Ukrainian)

3. Dąbkowski T. Ukraiński ruch narodowy w Galicji Wschodniej 1912-1923. Warszawa: PAN, 1985. c. 326.

4. Wolfram Dornik. The Emergence of Ukraine: Self-Determination, Occupation, and War in Ukraine, 19171922, 2015. $471 \mathrm{pp}$.

5. Pylypenko L.L., Bilan S.O. National Liberation Movement in Western Ukraine in the Interwar Period (1918-1939) // Relevant issues of development and modernization of modern science: the experience of countries of Eastern Europe and prospects of Ukraine: monograph / edited by authors. - Riga, Latvia: "Baltija Publishing", 2018. - pp. 284-300 